Jorunn Møller

Institutt for lcererutdanning og skoleforskning

Universitetet i Oslo

E-post: jorunn.moller@ils.uio.no

\title{
Kvalifisering som skoleleder i en norsk kontekst: Et historisk tilbakeblikk og perspektiver på utdanning av skoleledere
}

\section{Sammendrag}

Denne artikkelen har en dobbel målsetting. For det første er målet å gi et kort historisk tilbakeblikk over hva som har vœert gjennomført av skolelederopplcering i norsk regi i løpet av de siste 50 årene, da det gir en mulighet til å vise endringer som har skjedd over tid. For det andre er målet å drøfte dagens krav til kvalifisering av skoleledere i et internasjonalt perspektiv. Analysen av det historiske tilbakeblikket i en norsk kontekst bygger på dokumentanalyser og programevalueringer som har vœert gjennomført av de ulike programmene siden 1960-tallet. Drøftingen av forholdet mellom utdanningspolitikk og kunnskapsgrunnlag har fokus på hva slags kunnskap som er i bruk og hvorfor, og er inspirert av Gunters kategorisering av skoleledelse som forskningsfelt. I tillegg er internasjonale "handbooks" om utvikling av skoleledere viktige referanser.

Den historiske oversikten basert på erfaringer i Norge, gir et bilde av hva slags kompetanse man har hatt som intensjon å utvikle, og hvilke innholdselementer som har vart vurdert som viktige til ulike tider. Analysen viser at utdanningsprogrammene $i$ hovedsak henter teorigrunnlaget fra generell ledelsesteori og effektstudier, og i økende grad er den nasjonalt baserte utdanningspolitikken blitt påvirket av en internasjonal diskurs om kvalitet $i$ skolen hvor OECD i stor grad setter agendaen og legger premissene for utvikling av skoleledelse og praksis i skolen.

Nøkkelord: skolelederutdanning, utdanningspolitiske endringer, internasjonal kvalitetsdiskurs, skoleledelse som forskningsfelt

\section{Abstract}

This article has a double objective. Firstly, it aims to give a brief historical review of how school leadership development has been enacted in a Norwegian context during the last 50 years. Secondly, it aims to examine and discuss today's requirements of qualifications for school leadership in an international perspective. Policy documents focusing on school leadership development and external evaluations of the different development programs which have been offered to Norwegian school leaders since the 1960s serve as a departure for the 
analysis. The discussion of the relationship between educational policy and its knowledge base has a specific focus on what type of knowledge is used and why, and is inspired by Gunter's conceptual framework of an intellectual history of school leadership research. In addition, international handbooks on the preparation and development of school leaders are key references.

By applying a historical lens the analysis provides an image of the kinds of competencies that have been considered important over time. The findings show that the national programs for developing school leaders mainly draw upon general leadership theory and school effectiveness research, and increasingly they have become influenced by the international educational discourse about quality in school in which OECD has become a prominent agent in setting the agenda for improving school leadership and school practices.

Keywords: school leadership development, changes in educational policy, international quality discourse, theory traditions within leadership research

\section{Innledning}

Basert på internasjonal forskning om skole og kvalitetsutvikling trekkes ofte skoleledelse og skolelederutdanning fram som et avgjørende element når grunnskolen og videregående opplæring skal utvikles (Day \& Leithwood, 2007; Knapp et al., 2014; Leithwood \& Louis, 2012; Pont, Nusche \& Moorman, 2008; Robinson, 2011). I lang tid var USA nærmest enerådende når det gjaldt forskning om skoleledelse, og USA var også først ute med å stille krav til formell utdanning av skoleledere (Møller, 1995). Fram til begynnelsen av 1970tallet var skoleledelsesforskningen dominert av det som ble omtalt som "the theory movement” hvor målet var å finne fram til generelle lover for god skoleledelse slik at disse kunne fungere som en standardisert kunnskapsbase i opplæringen for skoleledere, og dermed utvikle skoleledelse som en profesjon atskilt fra undervisning (Griffiths, 1988).

Det viste seg imidlertid etter hvert å være høyst problematisk å bli enige om en slik standardisert kunnskapsbase. Med sitt skarpe skille mellom fakta og verdier ble tilhengerne av "the theory movement" kritisert for å betrakte ledelse og administrasjon som et teknisk problem der det å nå mål handlet om å utvikle administrative ferdigheter. A ekskludere verdier fra ledelsesforskningen var det samme som å ekskludere det menneskelige, ble det hevdet (Greenfield, 1979; Greenfield \& Ribbins, 1993). Videre ble nødvendigheten av å se skoleledelse i et historisk, kulturelt og samfunnsmessig perspektiv understreket (Bates, 1984; Foster, 1986). Kapitler i internasjonale "handbooks" om skoleledelse (Leithwood, Chapman, Corson, Hallinger \& Hart, 1996; Leithwood \& Hallinger, 2002), viser mangfoldet av perspektiver som etter hvert kom til å prege dette forskningsfeltet. I disse forskningsoversiktene fra 1996 og 2002 er det også 
bidrag basert på studier gjennomført i Europa, Australia og Asia. Senere er det utgitt tilsvarende "handbooks" om forskning relatert til skolelederutdanning (bl.a. Lumby, Crow \& Pashiardis, 2008; Young, Crow, Murphy \& Ogawa, 2009; Townsend \& MacBeath, 2011). Disse studiene viser at dagens situasjon er preget av ulike forskningstradisjoner og posisjoner der man er uenige om hvilke standarder som bør gjelde for god skoleledelse og god skolelederutdanning. Samtidig indikeres at noen posisjoner er mer dominerende enn andre, og dette blir blant annet utdypet i denne artikkelen.

I artikkelen gir jeg en historisk oversikt over hva som har vært gjennomført av skolelederopplæring i norsk regi de siste femti årene. Hensikten er å forankre dagens diskusjon om kvalifisering som skoleleder i en nær fortid og vise endringer som har skjedd over tid. I artikkelens siste del er målet å drøfte i et internasjonalt perspektiv hva som karakteriserer dagens kvalifisering til skoleledelse. Inspirert av Helen Gunters analyse av utdanningsreformer som ble gjennomført under New Labour fra 1997 til 2007 (Gunter, 2012) og hennes kategorisering av skoleledelse som forskningsfelt (Gunter, 2016), har jeg valgt følgende spørsmål som utgangspunkt for analysen: Hva karakteriserer innhold og kunnskapsgrunnlag i etter-og videreutdanning av skoleledere i Norge over tid, og hvilke aktører har stått sentralt? Hva preger forholdet mellom norsk skolelederutdanning og den internasjonale diskursen om kvalitet i skolen? Policydokumenter og nasjonale rammeplaner danner grunnlaget for analysen. I tillegg bygger den på funn fra eksterne evalueringer av de ulike programmene som over tid har vært tilbudt skoleledere i en norsk kontekst, og tidligere analyser som er gjennomført av skolelederutdanning i Norge.

\section{Etterutdanning for skoleledere i en norsk kontekst fra 1960 til 2000}

Ser vi tilbake i den nære skolehistorien, eksisterte det ikke noe statlig eller kommunalt tilbud om etterutdanning for skoleledere før 1960. Kursene som ble arrangert tidligere, var i regi av fagforeningene. Oversikten her tar utgangspunkt i det som har skjedd fra 1960 og fram til i dag.

\section{Sentrale og regionale administrasjonskurs: Voksenåskursene og Beite- kursene}

Etter påtrykk fra skolelederne selv, satte Kirke-, utdannings- og forskningsdepartementet (KUF) i gang årlige administrasjonskurs som gikk over seks uker fra og med 1963. Disse ble kalt Voksenåskursene. Emnene det ble undervist i, omfattet innføring i lovverket, saksbehandling, kontorhold og psykologi. I 1966 ble kurslengden redusert til fire uker, og to år senere til tre uker. Kapasiteten var imidlertid langt fra god nok til å fylle behovet, og etter hvert kom det kritikk mot at innholdet var for løsrevet fra den praktiske ledelsessituasjonen. Opplæringsloven som kom i 1969, la også mye sterkere vekt på skolelederens ansvar for 
pedagogisk utviklingsarbeid og arbeidsmiljø, og på dette området markerte skolelederne i grunnskolen et sterkt behov for etterutdanning (Flottorp, 1981, s. 27-28).

I 1970-årene ble skolelederopplæring en sentral oppgave for landets skoledirektører. I 1972 oppnevnte departementet en arbeidsgruppe som skulle planlegge en desentralisert etterutdanning av skoleledere i grunnskolen hvor skoledirektørene skulle ha gjennomføringsansvar ${ }^{1}$. Innholdet skulle ta hensyn til at forventningene til lederrollen var endret (Mediås, 1996, s. 462). Samarbeid, medbestemmelse og ansvarsdeling ble viktige stikkord, og det ble lagt stor vekt på arbeidsmiljøets betydning. I grunnkurset inngikk organisasjonsteori og organisasjonspsykologi. Disse kursene fikk navnet "Beite-kursene", oppkalt etter arbeidsgruppens formann, skoledirektør Lars Beite fra Stavanger. Kursene hadde ambisiøse mål som søkte å kombinere teoretisk innføring med anvendelse i praksis. Men kursvurderingene tydet på at intensjonene ikke ble fulgt opp med relevante arbeidsmetoder, og det viste seg å være vanskelig å få tak i kvalifiserte forelesere (Flottorp, 1981, s. 29).

\section{Miljø og ledelse i skolen (MOLIS)}

Toralf Tveiten gjennomførte i 1973 en undersøkelse av arbeidsmiljøet i skolen (Tveiten, 1975). Han konkluderte blant annet med at skolelederen sannsynligvis hadde en mye større innflytelse på skolens indre liv, arbeidsmiljø og trivsel enn man tidligere hadde antatt. Med dette som grunnlag engasjerte KUF Terje Seljelid til å revidere og videreutvikle skolelederopplæringen i grunnskolen. Et viktig mål var å utarbeide en etterutdanning som var mer i samsvar med moderne organisasjonsutvikling (Flottorp 1981, s. 29; Mediås, 1996, s. 462). I samarbeid med Skoledirektøren i Oslo og Akershus ble forprosjektet, “Arbeidsmiljøet i skolen” (AMIS) igangsatt. Året etter ble det videreført som "Prosjekt skolelederopplæring” (PS), men nå i regi av Grunnskolerådet (Johansen, 1986, s. 64-66). Prosjekt skolelederopplæring hadde som premiss at rektorfunksjonen syntes å være den viktigste forklaringsvariabelen når det gjaldt skolens arbeidsmiljø. Skolelederopplæring kunne derfor betraktes som et middel for skoleutvikling.

Den sterke forankringen til "Human Relations"-bevegelsen² ble kritisert (Briseid, 1984), men trass i kritikken ble dette premissgrunnlaget videreført i prosjektplanen for "Miljø og ledelse i skolen” (MOLIS) som startet i januar 1981 (Johansen \& Tjeldvoll, 1989a, s. 17). Prosjektet ble organisert i tre trinn (Johansen, 1986, s. 79): Innledningsvis var det et administrasjonskurs (A-del) som vektla forvaltningsmessige oppgaver som skoleleder. Dette kurset hadde et omfang på 5 dager og ble særlig anbefalt for nytilsatte. Neste trinn var et lederkurs hvor samarbeidsspørsmål stod sentralt (B-del), og denne delen hadde et omfang på 10-15 dager fordelt på 11/2 år. Tanken var at hele personalet skulle aktiviseres i periodene mellom kurssamlingene for skolelederne slik at leder- 
opplæringen kunne knyttes tettere til utviklingsarbeid på egen skole. En C-del ble tilbudt som en videreføring og som en oppfølging av skolelederne.

Det overordnete målet for MOLIS var å få alle ved den enkelte skole til å arbeide for et godt lærings- og arbeidsmiljø for elevene og for personalet ved skolen (Seljelid, 1982). Prosjektet fikk innholdsmessig en sterk prosess- og sosialpsykologisk orientering. Læreplan- og målsettingsprosesser fikk derimot liten eller ingen oppmerksomhet, og skolens styringsstruktur ble ikke tematisert (Tjeldvoll, 1987). I hovedsak handlet opplæringen om mellommenneskelige forhold som samarbeid, kommunikasjon og konfliktløsing. Dette preger materiellet som ble utviklet i tilknytning til lederopplæringen. 14 av 18 hefter handler om miljøutvikling og mellommenneskelige relasjoner.

Svein Egil Vestre (1985) fikk ansvar for å vurdere MOLIS. Hans vurdering ble basert på spørreskjema til deltakere på B-delen i 6 fylker. I sin konklusjon understreket han at det var svært problematisk å si om prosjektet hadde hatt den ønskete virkning som skoleutviklingstiltak, da prosjektet først og fremst hadde fungert som individuell opplæring av skolelederne. Som individuell opplæring syntes prosjektet imidlertid å ha hatt god målrealisering. Vestre reiste tvil om det var tjenlig å opprettholde den doble målsettingen om leder- og skoleutvikling i prosjektet.

Pedagogisk Forskningsinstitutt ved Universitetet i Oslo fikk dernest i oppdrag å sluttvurdere prosjektet. Denne evalueringen, som var basert på dokumentgransking, spørreskjema og intervju, konkluderte med at skolering av lederen ved skolen neppe var tilstrekkelig for å initiere og vedlikeholde utviklingsprosessen på en skole (Johansen \& Tjeldvoll, 1989a, 1989b). Hele kollegiet måtte tilbys kvalifisering på nødvendige områder hvis man ønsket skoleutvikling i forhold til elevene og læreplanens mål. De resultater som var mulig å registrere hos skoleledere, gikk på bevisstgjøring av holdninger og reaksjoner i det sosiale samspillet mellom mennesker. Noen skoleledere hevdet at de var blitt mer bevisst på pedagogiske og administrative oppgaver, men dette var vanskelig å dokumentere. Johansen og Tjeldvoll (1989a) pekte på inkonsistens ved målene, innholdet og valg av strategi, noe som sannsynligvis svekket muligheten til målrealisering.

Med denne evalueringen som bakteppe og med referanse til målstyring som styringsprinsipp i skolen ble et nytt nasjonalt program utviklet. Det ble kalt "Ledelse i skolen". ${ }^{3}$

\section{Ledelse i skolen (LIS)}

KUF la i 1988 fram en ny rammeplan, "Ledelse i skolen”, LIS (Grue \& Holen, 1988). Et overordnet mål var å utvikle en ledelseskultur grunnlagt på skolens mål og egenart, og tilpasset skolens nye utfordringer. Et LIS-sekretariat, med blant andre én av hovedaktørene bak MOLIS, ble oppnevnt i departementet. I begrunnelsen for utformingen av den nye planen, ble den manglende 
forankringen til styringslinja trukket fram som en svakhet ved MOLIS. Derfor skulle ikke lenger sekretariatet være plassert i Grunnskolerådet.

Programmet ble utarbeidet i nært samarbeid med alle skoledirektørene, som fikk ansvaret for operasjonaliseringen i sine fylker. Programmet ble eksplisitt knyttet til målstyring, som skulle være det overordnete organisasjons- og ledelsesprinsipp (Grunnskolerådet, 1988). I tillegg måtte prinsippet om medvirkning og medansvar, og prinsippet om likestilling mellom kjønnene ivaretas. Man anbefalte tilrettelegging av læring på flere arenaer for å motvirke den tradisjonelle kursmodellen. I planen ble det presisert at skoleutvikling var avhengig av at lærere ble gitt medansvar i ledelse av skolen, men på grunn av økonomiske rammer måtte midlene som var øremerket "Ledelse i skolen", prioriteres for personer med formelle lederstillinger i skolen. Som innhold vektla man skolens rolle i samfunnet, skolevurdering, læreplanforståelse og ledelse av lokal læreplanutvikling. Det ble også produsert mange LIS-hefter som skulle støtte opplæringen.

De ulike fylkene operasjonaliserte rammeplanen noe forskjellig, avhengig av lokale forutsetninger som tidligere erfaring, samarbeidspartnere, ressursgrunnlag, kompetanse og geografi. I Oslo og Akershus ble det på eget initiativ vektlagt ekstern vurdering fra starten av, og to hovedfagstudenter i pedagogikk ble engasjert i dette arbeidet for å få et fortløpende korrektiv til både planleggingen og gjennomføringen. Evalueringene viste at selv om egen arbeidsplass var framhevet som sentral læringsarena i departementets rammeplan, ble seminarvirksomhet og arbeid i nettverksgrupper det som fikk størst vekt. Det ble påpekt at de mange oppgavene i praksisfeltet konkurrerte kontinuerlig om skoleledernes tid og gjorde det problematisk å gå tilstrekkelig i dybden innenfor de temaene som ble introdusert i etterutdanningen (Ottesen, 1989; Askestad, 1993).

Asplan Analyse (1992) fikk av departementet i oppdrag å evaluere lederopplæringen nasjonalt. Den metodiske tilnærmingen bestod av dokumentgransking hvor policydokumenter, nasjonal rammeplan og fylkesvise handlingsplaner inngikk, og intervjuer med sentrale aktører i Kirke-, utdannings- og forskningsdepartementet og ved skoledirektørkontorene samt utvalgte skolesjefer, rektorer og inspektører. I tillegg gjennomførte de deltakende observasjon på seminarer i to fylker. De konkluderer med følgende i sin evalueringsrapport:

Det har skjedd en bevissthetshevning hos deltakerne som gir seg utslag i språk og tenkemåte, og det registreres et økt engasjement og en sterkere motivasjon for oppgaven som leder. Identifiseringen med en klar og tydelig lederrolle er merkbar, noe som muligens kan skape en viss frustrasjon i det øvrige personalet. Planleggingskompetansen er økt, medarbeidersamtaler er tatt i bruk, ledernes ensomhetsfølelse er redusert. (Asplan Analyse, 1992, s. 13ff)

Asplan Analyse påpeker selv at det er en rekke usikre faktorer knyttet til den resultatvurderingen de gir, da det er vanskelig å si noe om de mer langsiktige virkningene. Dessuten er det problematisk å isolere LIS fra andre forhold som 
har inntruffet samtidig. Det pedagogiske opplegget vurderes som godt, men lærestoffet spriker for mye, og programmet mangler operasjonelle resultatmål. Målstyringstenkningen hevdes å være svakt utviklet, og LIS-heftene som var utviklet for å støtte opplæringen, kritiseres av Asplan Analyse for å ha svært ujevn faglighet. I forslag til videreutvikling vektlegges en klarere forankring $\mathrm{i}$ styringslinja når det gjelder organisering og temavalg, og mer vekt på ledernes ferdighetstrening (se Asplan Analyse, 1992, s. 23 og s. 179).

På grunnlag av denne evalueringen og på grunnlag av en tilsvarende evaluering av lederopplæringen for videregående skole, LEVIS (Blichfeldt, 1992), utformet så departementet i 1992 et felles nasjonalt program for ledelsesutvikling i grunnskole og videregående opplæring, LUIS (KUF, 1992).

\section{Ledelsesutvikling i skolen (LUIS)}

LUIS-programmet var en oppfølging av Stortingsmelding 37 (1990-91) “Om organisering og styring i utdanningssektoren"4, og utviklingen av dette programmet skjedde parallelt med omorganiseringen av utdanningssektoren sentralt. Samordningen mellom skolelederopplæring i grunnskole og videregående skole ble relatert til utviklingen av en felles nasjonal læreplan. Nasjonal styring av skolen skulle blant annet sikres gjennom lederopplæring. I forordet til det nye programmet skrev daværende utdanningsminister Gudmund Hernes:

Gjennom program for Ledelsesutvikling i skolen vil KUF fremme ledelse på alle nivå i skoleverket, styrke opplæringen av den enkelte skoleleder og bidra til at alle i skolesamfunnet aktiviseres i utviklingen og forbedringen av det (KUF, 1992, s. 3).

I LUIS-programmet (KUF, 1992, s. 17-20) understrekes det at skolen opererer med gitte mål og rammer som gir skolen et stort handlingsrom for læring og utvikling, og det er innenfor dette handlingsrommet at skolen kan operere som en lærende organisasjon. Videre forutsetter man at både lærere og ledere er lojale mot skolens verdier og normer. Når arbeidsgiverrollen beskrives, framheves generelle prinsipper for ledelse som er utviklet innenfor privat sektor.

Kommuneloven (Ot.prp. nr. 42, 1991-92), som trådte i kraft 1. januar 1993, gjorde det videre problematisk å anvende LUIS-programmet som virkemiddel for nasjonal politisk styring av skolen. Skoleledere hadde for eksempel ifølge programmet plikt til å delta i opplæring som ble tilrettelagt regionalt i regi av skoledirektørene. Ifølge kommuneloven kunne imidlertid ikke departementet pålegge kommuner og fylkeskommuner å delta i spesielle utdanningsprogrammer. Kommuner og fylkeskommuner kunne selv bestemme om de ønsket at deres skoleledere skulle delta i etterutdanning som ble tilbudt i regi av skoledirektørkontorene (Møller, 1992, s. 313-314; Møller, 1995, s. 156).

På 1990-tallet ble det utviklet en ny kompetanseutviklingsstrategi som understreket nødvendigheten av samarbeid med høgskoler og universiteter. Samarbeidet mellom stat, kommune og høyere utdanningsinstitusjoner ble omtalt som det "strategiske triangel". For å stimulere utviklingen av tilbud fra 
universiteter og høgskoler initierte departementet i januar 1998 etableringen av nettverk mellom utdanningsinstitusjoner som tilbød etterutdanning for skoleledere. En sentral målsetting for nettverket var å oppnå en best mulig bruk av landets samlede kompetanse når det gjelder skolelederopplæring. Oppgavene omfattet utvikling av etterutdanning i pedagogisk ledelse som skulle være delvis IKT-basert for å øke tilgjengeligheten av utdanningstilbud i hele landet. Institutt for lærerutdanning og skoleforskning fikk en faglig koordineringsoppgave i nettverket.

Arbeidet innenfor dette nettverket resulterte i utvikling av delvis IKT-baserte undervisningsopplegg som omfatter fem hovedområder for pedagogisk ledelse basert på kompetansemålene i “Skuleleing mot år 2000” (KUF, 1996). Visjonen om den lærende, utviklingsorienterte og samarbeidende skolen ble formulert som utgangspunkt for forventningene til skoleledelsens kompetanse. Kompetanseutvikling skulle knyttes til de spesifikke lederutfordringene i skolen, med særlig vekt på utviklingsperspektivet og den pedagogiske lederfunksjonen. De fem områdene omfattet: 1) Utvikling, vurdering og kvalitet; 2) Læringsmiljøet; 3) Arbeidsgiveroppgaver; 4) Utdanningspolitikken og opplæringsloven; 5) Læreplanarbeid. Arbeidet ble imidlertid avsluttet før man rakk å sy sammen de ulike delemnene til en helhet. Resultatet ble dermed undervisningsopplegg som kunne inngå i en nasjonal idébank som ble koordinert av det daværende Læringssenteret ${ }^{5}$.

Agenda Utredning \& Utvikling gjennomførte på oppdrag fra Kirke-, utdannings- og forskningsdepartementet en ekstern evaluering av prosjektet høsten 2000. Oppdraget omfattet både en vurdering av hvordan prosjektet var styrt fra departementets side og effekter med særlig vekt på bruk og utvikling av IKT-støttede programmer. Med forbehold om metodiske problemer med å vurdere effekter av et slikt prosjekt, konkluderer Agenda med at organiseringen av Prosjektprogrammet LUIS sentralt i hovedsak har vært hensiktsmessig og fungert tilfredsstillende i lys av målene som var formulert, men Universitets- og høgskoleavdelingen burde ha vært representert i koordineringsgruppen for å skape legitimitet til iverksettingen innenfor høyere utdanningsinstitusjoner. De nasjonale konferansene $\mathrm{i}$ regi av departementet og det nasjonale nettverket ${ }^{6}$ framheves som avgjørende for måloppnåelse. Samarbeidet på tvers av høgskoler og universiteter ble opplevd som positivt og faglig givende, men det hadde også vist seg vanskelig å få alle institusjonene til å forplikte seg på samarbeid. I noen regioner hadde det også bydd på problemer å få KS (Kommunenes Sentralforbund) til å inngå forpliktende samarbeid, og fylkeskommunene hadde vært lite involverte. Tilbudene som var blitt utviklet, var bare delvis IKT-baserte, og tilbyderne hadde også støtt på en rekke tekniske, juridiske og pedagogiske problemer i utviklingen av IKT-baserte moduler (KUF, 2000).

Oversikten så langt viser at det gjennom mange år har vært satset ganske mye på opplæring av skoleledere i Norge i statlig regi. Tilbudene er blitt justert fortløpende basert på evalueringene som ble gjennomført. Teorigrunnlaget var i 
stor grad hentet fra ledelsesteori utviklet innenfor privat sektor hvor særlig organisasjonspsykologi og målstyring dannet en viktig basis. Generell didaktikk med vekt på læreplanteori kom først inn med programmet "Ledelse i skolen" (LIS). Innholdsmessig karakteriseres etterutdanningstilbudene som fragmenterte og i stor grad preget av en kursmodell med liten grad av forpliktelse for deltakerne.

\section{Ny kurs: Fra etterutdanning til videreutdanning}

\section{Utvikling av masterprogrammer for skoleledere}

I 2002 utlyste Utdannings- og forskningsdepartementet midler for å stimulere universitets- og høgskolemiljøene til å utvikle utdanning på mastergradsnivå for skoleledere. Arbeidet ble organisert gjennom Sentralorganet for fleksibel fjernundervisning (SOFF), nåværende Norgesuniversitetet. Dette resulterte i et omfattende samarbeid på tvers av høyere utdanningsinstitusjoner i hele landet (Vennebo, 2006), og i dag tilbyr mange universiteter og høgskoler mastergradsstudium innenfor skoleledelse. Hvordan kunnskap utvikles gjennom forskning i høgskoler og universiteter som tilbyr skolelederutdanning, og hva som er med på å skape et profesjonsgrunnlag for skoleledere i dagens samfunn, var og er gjenstand for fortløpende diskusjoner, ikke minst fordi det forventes at utdanningstilbudene ivaretar krav om høy kvalitet, fleksibilitet og implementering av ny læringsteknologi (Sivesind, Langfeldt \& Skedsmo, 2006). Parallelt har de statlige etterutdanningstilbudene til skolelederne opphørt, og departementet forventer at universiteter og høgskoler utvikler relevante og praksisnære kompetanseutviklingstilbud i samråd med kommuner og fylkeskommuner (UFD, 2004).

Ifølge kommuneloven har kommuner og fylkeskommuner ansvaret for sine skoler innenfor sentralt gitte rammer, og det innebærer at lokalpolitikerne har et viktig ansvar for utviklingen av skolene. De har dermed også det juridiske ansvaret for lederopplæringen. I praksis vil dette være delegert til administrativt nivå i kommunen. Den skoleansvarlige kan da velge om han eller hun vil kjøpe "utdanningspakker" fra ulike konsulentfirmaer, universiteter og høgskoler, eller om etaten selv skal ta ansvaret for gjennomføringen. Her konkurrerer universiteter og høgskoler med sine tilbud på samme marked som private firmaer. Avhengig av hva slags kompetanse som befinner seg på kommunalt nivå, og hva slags preferanser skoleeiere har, kan det bli både vilkårlig og svært ulikt hva slags etterutdanning som tilbys skolelederne lokalt.

\section{Utvikling av en nasjonal rektorutdanning}

I tidsrommet 2006-2008 deltok Norge i en sammenlignende studie av skoleledelse, Improving School Leadership, i regi av OECD ${ }^{7}$. Den rettet søkelyset mot ledelse, lederroller, rekruttering av ledere, arbeidsbetingelser for ledelse, 
lederopplæring og lederutvikling. Programmet hadde til hensikt å sammenstille forskning og praksis som er gjort med tanke på å forbedre lederskapet i skolen, og identifisere innovative og gode politiske initiativ. På denne måten ønsket OECD å bidra til utveksling av erfaringer, kunnskap og politikk mellom landene. Analysen var todelt. I første fase ble det gjennomført en kartlegging på tvers av land basert på et omfattende spørreskjema med åpne spørsmål (Pont, Nusche \& Moorman, 2008). I andre fase ble fem land (områder) valgt ut for mer kvalitative studier for å vise gode eksempler på systemledelse (Pont, Nusche \& Hopkins, 2008).

I studiens første fase skilte Norge seg ut som ett av få land som ikke hadde definert klare krav til formell utdanning av skoleledere. Sluttrapporten inneholdt konkrete anbefalinger om hvordan skoleledernes funksjon og rolle kunne utvikles og styrkes i de 22 landene som deltok (Pont, Nusche \& Moorman, 2008). Blant annet ble det foreslått at skoleledere skulle ha stor grad av autonomi, og samtidig tilbud om kontinuerlig lederopplæring. I særlig grad var det viktig å sikre opplæring av nytilsatte skoleledere. I opplæringen ble det videre anbefalt å ha en sterk vektlegging av den faglige ledelsesfunksjonen. I Stortingsmelding nr. 31 (2007-2008) ble det klart at Kunnskapsdepartementet ønsket å følge opp OECDs forslag. Departementet signaliserte i denne meldingen at de ville be Utdanningsdirektoratet om å igangsette en prosess for å definere innhold $\mathrm{i}$ en skolelederutdanning hvor den faglige og pedagogiske ledelsesfunksjonen skulle vektlegges (St.meld. nr. 31 (2007-2008), s. 66-67). Det ble også bestemt at omfanget på tilbudet skulle være 30 studiepoeng, og at studiet skulle kunne innpasses i en masterutdanning i skoleledelse. Utdanningen skulle i første omgang tilbys til nytilsatte rektorer og andre rektorer som manglet slik utdanning.

Kunnskapsdepartementet ønsket med andre ord å tydeliggjøre forventninger og krav til rektorer gjennom å regulere innholdet i skolelederutdanningen. Etter en anbudsrunde ga Utdanningsdirektoratet fire utdanningsmiljøer i oppdrag å tilby rektorutdanning fra og med høsten 2009, og fra og med høsten 2010 fikk to nye fagmiljøer tilsvarende oppdrag. Utdanningsdirektoratet har parallelt engasjert seg sterkt i å definere kunnskapsfeltet for norske skoleledere gjennom utviklingen av nasjonale rammeplaner, og har dermed fått rollen som sentral påvirkningsagent i en norsk kontekst (Møller \& Ottesen, 2011).

En analyse av ulike programmer viser at de tilbudene som gis, har ulik profil og kunnskapsgrunnlag, men alle er likevel definert som tilbud innenfor den nasjonale rektorutdanningen (Møller \& Ottesen, 2011). Dette indikerer at den nasjonale rammeplanen gir utdanningsinstitusjonene stor grad av autonomi og handlingsrom. Utdanningsdirektoratet har også bidratt til følgeevaluering av den nasjonale rektorutdanningen med NIFU i samarbeid med NTNU Samfunnsforskning som ansvarlig (Hybertsen, Stensaker, Federici, Olsen, Solem \& Aamodt, 2014). Evalueringen er omfattende og bygger på dokumentanalyser av styringsdokumenter og studieplaner, intervjuer med representanter fra hver 
programtilbyder, observasjoner og spørreundersøkelser. I første delrapport (Lysø, Stensaker, Aamodt \& Mjøen, 2011) pekes det på at rektorutdanningen har kjennetegn som er typiske for skolelederutdanning i andre land hvor skolens kjerneoppgaver utgjør sentralt innhold, og hvor arbeidsformene gir rom for individuell utvikling og nærhet til utøvelse av ledelse i praksis. Denne evalueringen viser at deltakerne er svært tilfredse med det tilbudet de har fått, og den pedagogiske kvaliteten og praksisrelevansen vurderes som spesielt god hos alle tilbyderne selv om fagprofilen er ulik. Deltakerne understreker videre at de opplever økt mestring i rollen som rektor og de opplever seg selv trygge i rollen som pedagogiske ledere og er tettere på undervisningen. Når det gjelder endringer som har skjedd i den lokale skole, er det vanskelig å relatere slike lokale endringer direkte til rektors deltakelse i utdanningen, da slike sammenhenger er komplekse. Siden oppstarten av programmet oppfatter svært mange rektorer at de har utviklet seg som ledere, de har etablert nye nettverk og læringsfellesskap, og dermed konkluderes det i evalueringen at dette indirekte kan ha bidratt til å styrke kvaliteten i skolen. Målet om å koble skoleeierne til utdanningen er imidlertid bare delvis oppfylt.

Oppsummert kan man si at de tiltak som er iverksatt etter 2000-årsskiftet, har gått i retning av videreutdanningstilbud som avsluttes med formell eksamen, og som gir innpassing til etablerte masterutdanningstilbud innenfor skoleledelse / utdanningsledelse for de som ønsker å ta en mastergrad innenfor ledelse. Selv om det ble utarbeidet en nasjonal rammeplan med presiseringer av innholdskomponenter, viser den store variasjonen på tvers av høgskoler og universiteter som tilbyr rektorutdanning, at det lokale handlingsrommet for utforming er stort. Evalueringene gir det samme inntrykket som tidligere. Den enkelte skoleleder opplever økt bevisstgjøring i lederrollen, men det er stor usikkerhet koblet til hva som skjer i praksis.

Med basis i oversikten over utdanningstilbud som har vært gitt og gis til skoleledere i Norge, vil jeg i artikkelens siste del rette søkelyset mot hva som har karakterisert innhold og kunnskapsgrunnlag over tid, hvilke aktører som har stått sentralt, og hva som preger forholdet mellom norsk skolelederutdanning og den internasjonale diskursen om kvalitet i skolen.

\section{Kunnskapsgrunnlaget i utdanning av skoleledere}

Det er en legitim forventning at utdanningsprogrammer som tilbys skoleledere, har en forankring i forskning om ledelse i og av skolen. Men forskningsfeltet om skoleledelse er som nevnt innledningsvis, preget av de mange perspektiver som henter sitt kunnskapsgrunnlag fra ulike disipliner som sosiologi, organisasjonspsykologi, statsvitenskap og antropologi. Pensumlitteraturen som anvendes i utdanningen av norske skoleledere, dokumenterer dette mangfoldet, og dette gir de ulike utdanningsinstitusjonene muligheter til å profilere sine tilbud om 
rektorutdanning ulikt (Møller \& Ottesen, 2011). Basert på forskning har vi etter hvert mye kunnskap om hvordan ledelsesutvikling i skolen foregår, men samtidig er det mulig å identifisere ulike forskningstradisjoner som konkurrerer om innflytelse og dominans. Derfor er det relevant å diskutere hvilke teoritradisjoner som dominerer i utformingen av skolelederopplæringen.

\section{Ulike forskningstradisjoner og utforming av skolelederopplæring}

I løpet av de siste tjue årene er det utgitt mange håndbøker som har som mål å fungere som en type "state of the art" når det gjelder forskning om skoleledelse og skolelederutdanning (se f.eks. Leithwood et al., 1996; Teddlie \& Reynolds, 2000; Leithwood \& Hallinger, 2002; Lumby et al., 2008; Young et al., 2009; Townsend \& MacBeath, 2011). Disse publikasjonene dokumenterer mangfoldet av perspektiver på skoleledelse. Videre er det gjort flere forsøk på å kategorisere ledelsesforskningen ut fra mer overordnete teoretiske rammeverk basert på studienes hensikter, metodologi og tenkning omkring skoleledelse ${ }^{8}$. Det kan være problematisk å kategorisere ofte siterte studier innenfor en bestemt tradisjon, men det er mulig å indikere hvor hovedvekten ligger. I denne artikkelen skilles det mellom:

a. Målrasjonelle eller effektstudier hvor målet er å avdekke generelle kjennetegn ved god skoleledelse og koble ledelsesatferd til elevenes skoleresultater. Oppmerksomheten er rettet mot hva som virker, standarder for god praksis og eksempler på "beste praksis"9.

b. Studier hvor målet er å forstå hvordan skoleledere tenker omkring og erfarer arbeidet som ledere; hvordan de skaper mening i arbeidet sitt, herunder hvordan de konstruerer sine lederidentiteter ${ }^{10}$ (f.eks. studier forankret i konstruktivistiske teorier).

c. Studier forankret i kritisk teori hvor målet er å avdekke maktstrukturer i samfunnet og hvordan dette påvirker forståelse av kjønn, klasse og rase (denne teorirammen er i stor grad inspirert av Pierre Bourdieu og Frankfurterskolen med Jürgen Habermas) ${ }^{11}$.

d. Studier forankret i postmoderne teorier som har som mål å dekonstruere etablerte sannheter og hvor analyse av makt og dominerende diskurser om skoleledelse står sentralt (denne teorirammen er i stor grad inspirert av Michel Foucaults maktanalyser $)^{12}$.

Innholdsoversikter og analyser publisert i internasjonale "handbooks" viser hvordan skoleledelsesforskningen innenfor engelsk-språklige land i stor grad har fått dominere den internasjonale diskursen om skoleledelse. Definisjonsmakten må ses i sammenheng med den økte samhandlingen mellom nasjonale og transnasjonale aktører og nettverk innenfor feltet, hvor det engelske språket er blitt helt dominerende i samarbeidet. Publisering på engelsk er avgjørende for å være i dialog med det internasjonale forskningsfeltet, men engelsk er også blitt 
dominerende språk innen nettverk blant dem som er administrativt ansvarlige for utvikling og gjennomføring av skolelederutdanningen nasjonalt. Da New Labour med statsminister Tony Blair gjorde skoleledelse til et dominerende tema innenfor utdanningspolitikken i England, var det også et sentralt mål å bli en viktig internasjonal påvirkningsagent. National College for School Leadership, NCSL, som ble etablert i 2000, fikk for eksempel raskt et bredt internasjonalt nedslagsfelt, noe som hadde sammenheng med solid økonomisk satsning og dannelse av faglige nettverk. I tillegg til å tilby rektorutdanning på ulike nivåer, utlyste og finansierte NCSL mye oppdragsforskning koblet til skoleledelse, og NCSL ble et viktig møtested for utdanningsbyråkrater fra mange land (Møller, 2014).

En studie av Helen Gunter (2012) er interessant i denne sammenheng. I samarbeid med kolleger undersøkte hun forholdet mellom offentlig utdanningspolitikk og kunnskapsregimer under New Labour fra 1997 til 2007 i England. Hensikten var å belyse følgende spørsmål: Hva slags type kunnskap anvendes i utdanningspolitikken og hvorfor? Hvem er forskerne som bidrar med kunnskapsgrunnlaget i denne sammenhengen og hvorfor? Studien viser for det første hvordan effektstudier fikk en dominerende plass som legitimt kunnskapsgrunnlag i lederutdanningen i regi av NCSL, mens studier som var forankret i kritiske og postmoderne teorier ble marginalisert. For det andre var det en klar preferanse for kvantitative effektstudier som kunne gi svar på hva som virker i praksis. For det tredje var det først og fremst forskere innenfor forskningstradisjonen School Effectiveness and School Improvement (SESI) som ble anerkjent som leverandører av forskningsresultater, mens forskere innenfor for eksempel utdanningssosiologi ble marginalisert. Gunter viste hvordan skolelederutviklingen i stor grad ble svært instrumentell og et verktøy for statlig styring av skolene. Dette argumentet støttes også av andre analyser av engelsk skolelederopplæring, f.eks. Bolam (2004), Brundrett (2000) og Thrupp (2005). Et nærliggende spørsmål er om dette gjelder norsk skolelederopplæring.

Politikere er med nødvendighet handlingsorientert, og de forventer at forskning skal bidra med svar på utfordringer som skolen står overfor. Dermed har gjerne studier som måler eller undersøker hva som er effektive eller gode skoler, stor appell når de hevder å vise hva som virker i skolen, framfor studier som problematiserer skolen som en kompleks organisasjon.

\section{Kvalifisering til skoleledelse - kunnskapsgrunnlaget i en norsk kontekst}

Oversikten viser at kunnskapsgrunnlaget har endret seg i takt med at nye perspektiver innen utdanningspolitikk og forskning om skoleledelse vant fram. I utgangspunktet var det administrasjon og lovreguleringen av skolen som stod sentralt i Voksenåskursene. Lenge var også erfaring fra fagforeningsarbeid en viktig kvalifikasjon når man søkte jobb som skoleleder, da et slikt tillitsverv innebar godt kjennskap til lovverket. Da etterutdanningsprogrammet "Miljø og ledelse”, MOLIS, ble introdusert, var det primært generell organisasjonspsykologi og motivasjonsteori som utgjorde det sentrale kunnskapsgrunnlaget. 
Man var opptatt av hvordan man kunne få en bedre tilpasning mellom menneskers behov, evner og verdier på den ene siden, og deres formelle roller og relasjoner på den andre siden. Ledernes mellommenneskelige innsikt ble ansett som avgjørende for utviklingen av organisasjonen. Mye av teorigrunnlaget, var hentet fra studier av ledelse i privat sektor ${ }^{13}$, men det ble også hentet mye inspirasjon for norsk skolelederopplæring i amerikanske studier om skole og skoleledelse (jf. Mediås, 1996, s. 386).

Mens kunnskapsgrunnlaget i amerikansk skolelederutdanning i stor grad var preget av rasjonalistiske systemmodeller, fikk dette, med unntak av den såkalte Kenning-tradisjonen, ikke stor plass i en norsk kontekst før sent på 1980-tallet (Strand, 2001, s. 102). Men da MOLIS ble etterfulgt av "Ledelse i skolen”, LIS, og noe senere "Ledelsesutvikling i skolen”, LUIS, fikk målstyring, virksomhetsplanlegging, skolevurdering og læreplananalyse en sentral plass i tillegg til generell ledelsesteori basert på sosiologi og organisasjonspsykologi. Generelt sett satte en styringslogikk kjennetegnet av sterk og synlig ledelse, samt resultatog prestasjonsorientert ansvarliggjøring, dagsorden for moderniseringen av offentlig sektor (Christensen \& Lægreid, 2011). Med sin vekt på planlegging, effektivisering og kontroll kan utformingen av denne styringsstrategien karakteriseres som instrumentell (Karlsen, 2014, s. 125).

Denne styringslogikken er tydelig i den nasjonale rektorutdanningen som styres fra Utdanningsdirektoratet. Nasjonale og lokale myndigheter signaliserer at prestasjoner på nasjonale prøver i lesing, regning og engelsk skal danne grunnlag for kvalitetsutvikling på alle nivåer i skolesystemet, og dermed er bruk og oppfølging av slike resultater et viktig innhold i skolelederutdanningen. I tillegg har skolejuss og forvaltningsrett igjen fått økt betydning, noe som høyst sannsynlig har sammenheng med økt rettsliggjøring i samfunnet (Jakhelln \& Møller, 2016). I likhet med analysen av skolelederopplæringen i England (Gunter, 2012) er studier basert på kritisk teori i stor grad marginalisert i den pensumlitteraturen som anvendes, selv om innholdet som tilbys av ulike institusjoner varierer (Møller \& Ottesen, 2011). Studiet skal være praksisnært og et verktøy for gjennomføring av nasjonal utdanningspolitikk.

\section{Sentrale aktører i utformingen av norsk skolelederopplæring}

Som vist i den historiske oversikten spilte skoledirektørene en viktig rolle i skolelederopplæringen fram til 1992 da det skjedde en omorganisering av den statlige utdanningsadministrasjonen i tråd med nye målstyringsprinsipper, og den enkelte kommune fikk et klart ansvar for etterutdanning av egne skoleledere.

Gjennomgående har nasjonalt nivå vurdert skolelederopplæring som en måte å styre skolen på i riktig retning, men det var først med St.meld. nr. 37 (199091) at lederopplæring ble eksplisitt presisert som virkemiddel for å realisere målstyring i skolen (Møller, 1992). Som vist i den historiske oversikten var skoledirektørene nøkkelpersoner i utformingen av skolelederopplæringen fram 
til den regionale utdanningsadministrasjonen ble omorganisert på 1990-tallet. I 2000 ble oppgaven delegert til Læringssenteret, som i 2004 ble erstattet av Utdanningsdirektoratet.

Sentrale aktører i Utdanningsdirektoratet erkjenner at de har hatt en viktig påvirkningsrolle i utformingen av den nasjonale rektorutdanningen, og skriver at representanter for direktoratet i tidsrommet 2005-2009 reiste "land og strand rundt og holdt faglige foredrag om ledelse, samt drøftet ledelsesspørsmål med alle interessenter, aktører og aktuelle fagmiljøer i sektoren” (Tronsmo, 2014, s. 72). Hensikten var å gjøre det "stuerent og aktuelt å anerkjenne ledelse som viktig” (ibid., s. 69), og bidra til å sikre et nasjonalt mandat til å sette fart i satsing på skoleledelse. I tillegg var det viktig å legitimere Utdanningsdirektoratets sentrale rolle i videre utvikling av rammeverk for rektorutdanningen.

Samtidig har samarbeidet med OECD om utdanningspolitiske spørsmål akselerert de siste femten årene. I tillegg til deltakelse i mange internasjonale kunnskapstester og kartlegginger, deltar representanter fra departement og direktorat jevnlig på konferanser og nettverksmøter som arrangeres i regi av OECD og OECDs senter for utdanningsforskning og innovasjon (CERI) som leder internasjonale kartleggingsstudier, gjennomfører casestudier av "beste praksis” og kommer med klare anbefalinger basert på de studiene de har initiert (f.eks. OECD, 2013). På denne måten bidrar OECD til en internasjonal kvalitetsdiskurs (Ozga, Dahler-Larsen, Segerholm \& Simola, 2011).

\section{Kobling mellom internasjonale reformideer og legitimt kunnskapsgrunnlag}

Vi vet at utdanning står sentralt på den politiske agendaen i alle OECD-landene, og utdanning oppfattes ikke bare som en sentral faktor for å løse sosiale problemer, men også i relasjon til de økonomiske utfordringene, da utdanning betraktes som et virkemiddel i den økonomiske konkurransen landene imellom. Kunnskap og kompetanse, eller utdanning som humankapital, framheves som vår viktigste konkurransefaktor i en global kunnskapsøkonomi (Karlsen, 2014). Parallelt har vi fått et nytt internasjonalt språk om utdanning og kvalitet som er tilpasset en økonomisk logikk hvor utdanning omtales som en vare man kan skaffe seg på et marked, og hvor skoler konkurrerer om kunder. Ledelsesmodeller hentet fra privat sektor settes opp som forbilde (Møller, 2007), og dette bidrar til å forklare hvorfor ledelsesteorier og effektmålinger er blitt et legitimt kunnskapsgrunnlag for skoleledere.

Analyser av policydokumenter har vist klare koblinger mellom det som norske myndigheter anerkjenner som sentralt kunnskapsgrunnlag i den nasjonale rektorutdanningen og internasjonale reformideer om modernisering av offentlig sektor, ofte omtalt som new public management (Møller \& Skedsmo, 2013). I norske stortingsmeldinger om utdanning legitimeres ofte tiltak med referanse til OECD når tiltakene begrunnes ${ }^{14}$, og dette indikerer stor innflytelse. I en norsk kontekst var det særlig publiseringen av PISA-resultatene på 2000-tallet som 
bidro til å skjerpe nasjonale myndigheters oppmerksomhet omkring elevers resultater. Både rektorer og lærere må i dag forholde seg til en kvalitetsdiskurs som er basert på resultater fra nasjonale tester og internasjonale undersøkelser. Det påvirker hva som blir oppfattet som legitimt kunnskapsgrunnlag for skoleledere. Studier som kan påvise hvilken effekt skoleledelse har på elevresultater, gis høy legitimitet som kunnskapsgrunnlag både i utformingen av skolelederutdanning, i finansiering av forskning og i utdanningspolitikk mer generelt (Karlsen 2014; Møller \& Ottesen, 2011; Møller, 2014). Selv om det er stor usikkerhet knyttet til slike effektmålinger og det er vanskelig gjennom forskning å påvise hva slags effekt skoleledelse har på elevenes læring, synes det å være en allmenn oppfatning at ledelse er løsningen på skolens problemer når utdanningspolitikk utformes og legitimeres.

De siste tjue årene har det også pågått et omfattende arbeid for å reformulere «skolespråket». Det handler om “å selge inn” de begrepene som ses som betydningsfulle for å få til endring, og å diskreditere deler av det eksisterende språket (Karseth \& Møller, 2014). Betydningen av tydelig og kraftfull ledelse ble for eksempel understreket i St.meld. nr. 30 (2003-2004) og satt i kontrast til føyelige aspekter ved skoleledelse som var uønsket i norsk skole. Gjennom betegnelsen "føyelig” diskrediteres ledere som gir de profesjonelle selv, dvs. lærerne, et betydningsfullt ansvar. Mens å være føyelig er et entydig negativt begrep i denne sammenhengen, er kraftfull positivt. Språkbrukens klare definering av det positive og det negative gjør at eventuelle spenninger i lederjobben i liten grad gis plass, og ledelsespraksis hentet fra privat sektor ble satt opp som forbilde. Krediteringen av tydelig lederskap innebærer også en legitimering av et resultatansvar utover det som tidligere har ligget i skolelederrollen. Det blir forventet at rektorene forholder seg til en ny diskurs om kvalitet som er basert på resultater fra nasjonale tester og internasjonale undersøkelser (Karseth \& Møller, 2014). Denne vendingen i synet på skoleledelse har også klare linjer til en internasjonal styringsdiskurs som vektlegger målstyring, standarder, vekt på resultatfokus og ekstern ansvarliggjøring (Evetts, 2009).

\section{Avsluttende kommentar}

Analysen i denne artikkelen har vist at gjennomgående har skoledirektørene og senere Utdanningsdirektoratet spilt en sentral rolle i utformingen av rammeplaner for skolelederutdanningen i Norge. Programmene har i stor grad hentet sitt teorigrunnlag fra generell ledelsesteori, samtidig som ulike fagdisipliner har dominert innhold til ulike tider. Mens innholdet i skolelederutdanningen på slutten av 1970-tallet og første halvdel av 1980-tallet i stor grad var preget av sosialpsykologisk forskning om ledelse og utvikling av organisasjoner, bidro det utdanningspolitiske skiftet som satte målstyring i system i en norsk kontekst, til 
større vekt på rasjonelle ledelsesteorier og styring av utdanning hvor effektstudier dannet et viktig kunnskapsgrunnlag.

I løpet av de 50 årene som har gått siden de første etterutdanningskursene for skoleledere, har det skjedd en forskyvning fra en i hovedsak nasjonalt basert utdanningspolitikk til en stadig sterkere internasjonal innflytelse på hva som kjennetegner den gode skole. I denne prosessen har OECD spilt en sentral utdanningspolitisk rolle, og perspektiver på kvalifisering til skoleledelse er i økende grad blitt påvirket av en internasjonal diskurs om kvalitet i skolen. En sterkere prestasjonsorientert ansvarliggjøring synes å være gjennomgående både i den internasjonale og den norske diskursen om skoleledelse og kvalitet i skolen etter år 2000. Et hovedargument er at selv om utdanningsreformer bestemmes innenfor en nasjonal kontekst, er de også forankret i internasjonale strømninger og forventninger. Nye aktører og institusjoner på et overnasjonalt nivå griper inn i den nasjonale utdanningsdiskursen ved å utfordre tradisjonelle ordninger og tenkemåter. Slike forventninger har normsettende kraft og påvirker både språket vårt om skoleledelse og styring og tilrettelegging av skolelederutdanning.

\section{Referanser}

Askestad, T. (1993). Kan skoleledelse læres? Ledelse og lederutvikling i den norske grunnskolen. Hovedoppgave i sosialpedagogikk. Pedagogisk forskningsinstitutt, Universitetet i Oslo.

Asplan Analyse (1992). Evaluering av Ledelse i skolen (LIS). Lereplan - organisering gjennomføring - resultat. Asplan Analyse a.s.

Bates, R. (1984): Toward a Critical Practice of Educational Administration. I T. J. Sergiovanni \& J. E. Corbally (red.), Leadership and Organizational Culture. New Perspectives on Administrative Theory and Practice. Urbana and Chicago: University of Illinois Press.

Blichfeldt, J. F. (1992). Evaluering av Ledelse i Videregående Skole (LEVIS) - Nasjonal rapport. Rapport 9/92. Oslo: Arbeidsforskningsinstituttet.

Bolam, R. (2004). Reflections on the NCSL from a historical perspective. Educational Management, Administration and Leadership, 32(3), 251-267.

Briseid, L. G. (1984): Miljø og ledelse i skolen. Hvorfor, hva og hvordan? Pedagogisk Forskningsinstitutt, Universitetet i Oslo.

Brundrett, M. (2000). The Question of Competence: The Origins, Strengths, and Inadequacies of a Leadership Training Paradigm, School Leadership and Management, 20(3), 353-369.

Christensen, T. \& Lægreid, P. (2011). Beyond NPM? Some development features. I T. Christensen \& P. Lægreid (red.), The Ashgate research companion to new public management (s. 391-403). Farnham, England: Ashgate Publishing Ltd.

Day, C. \& Leithwood, K. (red.) (2007). Successful Principal Leadership in Times of Change. An International Perspective. Dordrecht: Springer.

Evetts, J. (2009). New professionalism and New Public Management: Changes, continuities and consequences. Comparative Sociology, 8(2), 247-266.

Flottorp, E. (1981). Rektorstillingen i fokus. Oslo: Aschehoug.

Foster, W. (1986). Paradigms and Promises. New Approaches to Educational Administration. New York: Prometheus Books. 
Greenfield, T. B. (1979). Research in Educational Administration in the United States andCanada: An overview and critique. Educational Administration, 8(1), 207-245.

Greenfield, T. B. \& Ribbins, P. (1993). Greenfield on Educational Administration, towards a Human Science. London: Routledge.

Griffiths, D. E. (1988). Administrative theory. I N. J. Boyan (red.), Handbook of Research on Educational Administration (s. 27-39). New York and London: Longman.

Grue, E. \& Holen, G. (1988). Vi lærer så lenge vi evaluerer. Om ledelsesutvikling og evaluering. Norsk Pedagogisk Tidsskrift, 72(5).

Grunnskolerådet (1988). Rammeplan for ledelsesutvikling i grunnskolen. Oslo: Grunnskolerådet.

Gunter, H. (2012). Leadership and the reform of education. Bristol: Policy Press.

Gunter, H. (2016). An Intellectual History of School Leadership Practice and Research. London: Bloomsbury.

Hybertsen, I. D., Stensaker, B., Federici, R. A., Olsen, M. S., Solem, A. \& Aamodt, P. O. (2014). Ledet til endring. Nasjonal rektorutdanning i grunn- og videregående skole; endringer på skolene, måloppnåelse og anbefalinger. NIFU og NTNU Samfunnsforskning.

Jakhelln, H. \& Møller, J. (2016). Retten i skolen - styring og sikring. I K. Andenæs \& J. Møller (red.), Retten i skolen - mellom pedagogikk, juss og politikk (s. 27-39). Oslo: Universitetsforlaget.

Johansen, K. (1986). Skoleutvikling og kvalifiseringsbehov. Hovedfagsoppgave. Pedagogisk Forskningsinstitutt, Universitetet i Oslo.

Johansen, K. \& Tjeldvoll, A. (1989a). Skoleledelse og skoleutvikling - en pedagogisk evaluering av programinnhold og gjennomføring av etterutdanningsprosjektet «Miljø og ledelse i skolen». Oslo: Solum Forlag.

Johansen, K. \& Tjeldvoll, A. (1989b). Skoleutvikling og lederopplæring. En presentasjon av sluttevalueringen av «Miljø og ledelse i skolen» (MOLIS). Norsk Pedagogisk Tidsskrift, 73(2).

Karlsen, G. (2014). Internasjonale aktører som premissgivere for norsk utdanningspolitikk med særlig vekt på OECD. I K. A. Røvik, T. V. Eilertsen \& E. M. Furu (red.), Reformideer i norsk skole. Spredning, oversettelse og implementering (s. 121-145). Oslo: Cappelen Damm.

Karseth, B. \& Møller, J. (2014). "Hit eit steg og dit eit steg”. Et institusjonelt blikk på reformarbeid i skolen. Norsk pedagogisk tidsskrift, 98(6), 452-468.

Knapp, M. S., Honig, M. I., Plecki, M. L., Portin, B. S. \& Copland, M. A. (2014). LearningFocused Leadership in Action. Improving Instruction in Schools and Districts. New York, NY: Routledge.

KUF (1992). Ledelsesutvikling i skolen. Prinsipper og mål for ledelsesutvikling i grunnskole og videregående opplæring, (LUIS). Oslo: PEDLEX Norsk skoleinformasjon.

KUF (1996). Skuleleiing mot år 2000. Kompetansemål for pedagogisk leiing i skulen innafor LUIS-programmet. Rundskriv F-24-96. Oslo: Kirke-, utdannings- og forskningsdepartementet.

KUF (2000). Evaluering av prosjektprogrammet LUIS. Agenda utredning og utvikling as. Oslo: Kirke-, utdannings- og forskningsdepartementet.

Leithwood, K., Chapman, J., Corson, D., Hallinger, P. \& Hart, A. (red.) (1996). International Handbook of Educational Leadership and Administration. Dordrecht: Kluwer Academic Publishers.

Leithwood, K. \& Hallinger, P. (red.) (2002). Second International Handbook of Educational Leadership and Administration. Dordrecht: Kluwer Academic Publishers. 
Leithwood, K. \& Louis, K. S. (2012). Linking Leadership to Student Learning. San Francisco. Jossey-Bass.

Lumby, J., Crow, G. \& Pashiardis, P. (red.) (2008). International Handbook of the Preparation and Development of School Leaders. New York, NY: Routledge.

Lysø, I. H., Stensaker, B., Aamodt, P. O. \& Mjøen, K. (2011). Ledet til ledelse: nasjonal rektorutdanning i grunn- og videregående skole i et internasjonalt perspektiv. Første delrapport i evalueringen av rektorutdanningen. NTNU Samfunnsforskning.

Mediås, O. A. (1996). Skoledirektørembetet i Norge 1860-1992. Oslo: Kirke-, utdannings- og forskningsdepartementet.

Meld. St. 20 (2012-2013). På rett vei. Kvalitet og mangfold i fellesskolen. Oslo: Kunnskapsdepartementet.

Meld. St. 28 (2015-2016). Fag - Fordypning - Forståelse - En fornyelse av Kunnskapsløftet. Oslo: Kunnskapsdepartementet.

Møller, J. (1992). Lederopplæring som styringsstrategi i skolen. Norsk pedagogisk tidsskrift, 76(6), 308-319.

Møller, J. (1995). Rektor som pedagogisk leder - i spenningsfeltet mellom forvaltning, tradisjon og profesjon. Avhandling for dr.polit-graden. Pedagogisk forskningsinstitutt, Universitetet i Oslo.

Møller, J. (2007). Educational Leadership and the New Language of Learning. International Journal of Leadership in Education, 10(1), 31-49.

Møller, J. \& Ottesen, E. (2011). Building Leadership Capacity: The Norwegian Approach. I T. Townsend \& J. MacBeath (red.), International Handbook of Leadership for Learning (s. 619-635). Dordrecht: Springer.

Møller, J. \& Skedsmo, G. (2013). Modernizing education - NPM reform in the Norwegian education system. Journal of Educational Administration \& History, 45(4), 336-353.

Møller, J. (2014). Ledelse som masteridé i norsk skole sett i et internasjonalt perspektiv. I K. A. Røvik, T. V. Eilertsen \& E. M. Furu (red.), Reformideer i norsk skole. Spredning, oversettelse og implementering (s. 148-165). Oslo: Cappelen Damm.

OECD (2013). Leadership for $21^{\text {st }}$ Century Learning. Educational Research and Innovation, OECD Publishing. doi: http://dx.doi.org/10.1787/9789264205406-en

Ottesen, E. (1989). Ledelse og lederutvikling i grunnskolen. Evaluering av et lederopplæringsprosjekt. Hovedoppgave i sosialpedagogikk. Pedagogisk forskningsinstitutt, Universitetet i Oslo.

Ozga, J., Dahler-Larsen, P., Segerholm, C. \& Simola, H. (2011). Fabricating quality in education: data and governance in Europe. London: Routledge.

Pont, B., Nusche, D. \& Moorman, H. (2008). Improving School Leadership. Volume 1: Policy and Practice. OECD-publishing.

Pont, B., Nusche, D. \& Hopkins, D. (2008). Improving School Leadership. Volume 2: Case Studies on System Leadership. OECD-publishing.

Robinson, V. (2011). Student-Centered Leadership. San Francisco: Jossey-Bass.

Seljelid, T. (1982). Miljø og ledelse i skolen: Håndbok. Oslo: Universitetsforlaget.

Sivesind, K., Langfeldt, G. \& Skedsmo, G. (2006). Utdanningsledelse. Oslo: Cappelen Akademisk Forlag.

St.meld. nr. 37 (1990-1991). Om organisering og styring i utdanningssektoren. Oslo: Kirke-, utdannings- og forskningsdepartementet.

St.meld. nr. 30 (2003-2004). Kultur for læring. Oslo: Utdannings- og forskningsdepartementet.

St.meld. nr. 31 (2007-2008). Kvalitet i skolen. Oslo: Kunnskapsdepartementet.

Strand, T. (2001). Ledelse, organisasjon og kultur. Oslo: Fagbokforlaget. 
Teddlie, C. \& Reynolds, D. (red.) (2000). The International Handbook of School Effectiveness Research. London: Falmer Press.

Thrupp, M. (2005). The National College for School Leadership: a critique. Management in Education, 19(2), 13-19.

Tjeldvoll, A. (1987). Ledelsesfunksjon, lærerkvalifisering og skoleutvikling. I T. V. Eilertsen, G. Grepperud \& T. Tiller (red.), Nye kurs eller ny kurs? Om skoleutvikling, etterutdanning og kompetanseheving. Oslo: Tano.

Townsend, T. \& MacBeath, J. (red.) (2011). International Handbook of Leadership for Learning. Dordrecht: Springer.

Tronsmo, P. (2014). Ledelse i skolen. Nye holdninger gir resultater. Bedre skole, nr. 3, 69-75. Tveiten, T. (1975). Klimaet i skolen. Norsk pedagogisk tidsskrift, 59(8).

UFD (2004). Kompetanse for utvikling. Strategi for kompetanseutvikling i grunnoppleringen 2005-2008. Oslo: Utdannings- og forskningsdepartementet.

Vennebo, K. F. (2006). Nasjonalt nettverk for skoleledelse. Rapport til Utdanningsdirektoratet. Det utdanningsvitenskapelige fakultet, Universitetet i Oslo.

Vestre, S. E. (1985). Evaluering av Miljø og ledelse i skolen. Oslo: Grunnskolerådet. Young, M., Crow, G., Murphy, J. \& Ogawa, R. (red.) (2009). Research on the Education of School Leaders. New York, NY: Routledge.

\footnotetext{
${ }^{1}$ Mange av skoledirektørene som ble utnevnt i perioden 1954-1975 hadde hovedfag eller magistergrad i pedagogikk og representerte en ny kategori sammenlignet med tidligere. Ti av skoledirektørene den gangen hadde foretatt studier i USA som på den tiden var vårt store forbilde (Mediås, 1996, s. 386).

${ }^{2}$ Refererer til organisasjonsforskere som studerte hva slags effekter sosiale relasjoner, motivasjon og tilfredshet på arbeidsplassen hadde på bedrifters produktivitet. Har sin opprinnelse i Hawthorne-studiene på 1930-tallet. Forretningsideen "Human resource management" er en videreutvikling.

${ }^{3}$ Parallelt ble "Ledelse i Videregående Skole”, LEVIS, etablert med tilsvarende begrunnelser.

${ }^{4}$ Målstyring ble i denne meldingen understreket som gjeldende styringssystem for utdanningssektoren.

${ }^{5}$ Nasjonalt senter for læring og utvikling (Læringssenteret) ble opprettet 1. august 2000, og målet var å bidra til et helhetlig perspektiv på læring, forsøks- og utviklingsarbeid, forskning og vurdering. I hovedsak skulle evaluerings- og utviklingsfunksjonene være knyttet til grunnskolen og videregående opplæring. Læringssenteret ble i 2004 erstattet av Utdanningsdirektoratet.

${ }^{6}$ Det nasjonale nettverket var åpent for alle høyere utdanningsinstitusjoner som tilbød etter- og videreutdanning for skoleledere, og inkluderte representanter fra de statlige utdanningskontorene, KS og fagforeninger.

${ }^{7}$ Organisation for Economic Co-operation and Development.

${ }^{8}$ Se f.eks. inndelingen som Lysø mfl. (2011, s. 25-26) har valgt i første delrapport til evalueringen av rektorutdanningen. En annen variant er valgt av Strand (2001, s. 30-31) som har kategorisert generelle ledelsesteorier ut fra organisasjonstype og lederorienteringer.

${ }^{9}$ Eksempler på ofte siterte forskere innenfor denne teorirammen er Day, Hallinger, Harris, Leithwood, Robinson.

${ }^{10}$ Eksempler på ofte siterte forskere innenfor denne rammen er Greenfield, Hargreaves, Lumby, Spillane, Wenger.

${ }^{11}$ Eksempler på ofte siterte forskere er Anderson, English, Foster, Gronn, Gunter, Hoyle.

${ }^{12}$ Eksempler på ofte siterte forskere er Ball, Blackmore, Thomson.

${ }^{13}$ Innenfor generell ledelsesutvikling i Norge kom Solstrandprogrammet, som var preget av arbeidspsykologi, til å få stor innflytelse på tenkningen omkring ledelse. Det ble startet i 1952 og har fremdeles stor innflytelse. Her har organisasjonsteori, motivasjonsteori og gruppeutvikling vært grunnelementer (Strand, 2001, s. 100-101).

${ }^{14}$ Som eksempler kan nevnes St.meld. nr. 31 (2007-2008) Kvalitet i skolen hvor det ble henvist 32 ganger til OECD i legitimeringen av tiltak, søk i Meld. St. 20 (2012-2013) På rett vei. Kvalitet og mangfold i fellesskolen ga 47 treff, mens søk i Meld. St. 28 (2015-2016) Fag - fordypning - forståelse - En fornyelse av Kunnskapsløftet ga 23 treff hvorav 14 var i litteraturlista.
} 